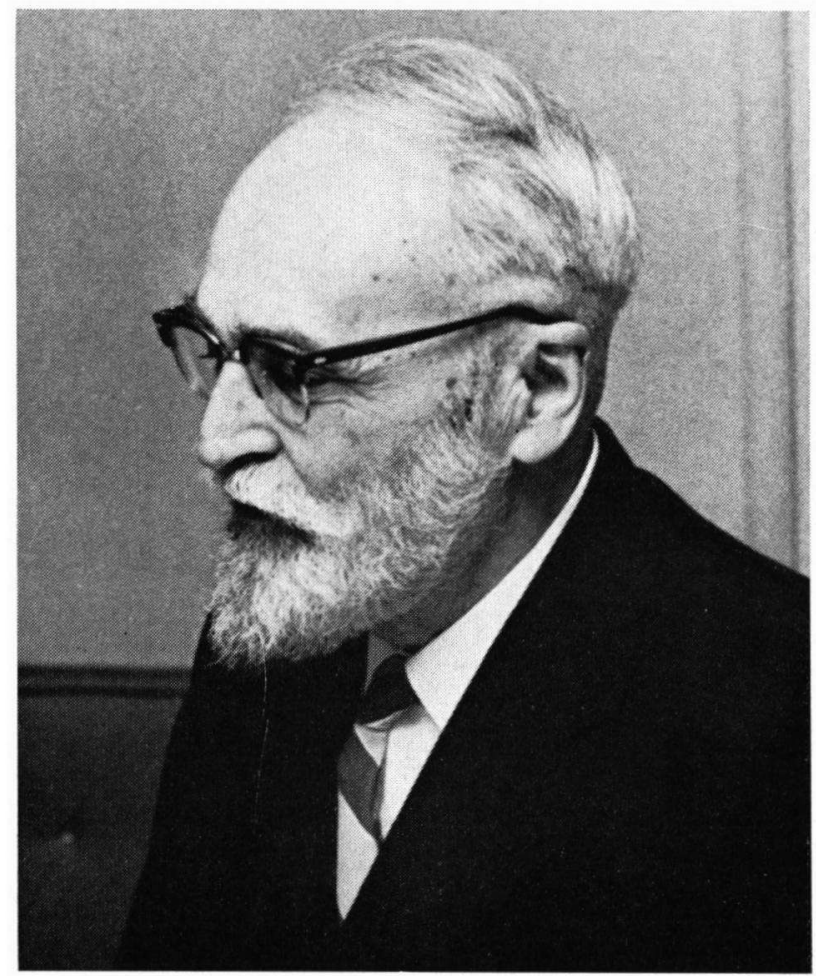

Photogr. by P. Slagmolen, Utrecht

\title{
Cornelius Elisa Bertus Bremekamp
}

Cornelis Elisa Bertus Bremekamp was born at Dordrecht on February 7th 1888. He is therefore now just past eighty, and he has been a member of the Koninklijke Nederlandse Botanische Vereniging for sixty years. He studied at the Utrecht State University and, like many of his contemporaries, was strongly attracted to plant physiology under Prof. F. A. F. C. Went's influence. Phototropy and geotropy had become the principal fields of research in Went's wellequipped laboratory, and Bremekamp's first scientific work was also devoted to these subjects. His thesis (1912) dealt with the Geotropy of Twining Plants. His publications of the following years were the results of similar studies. In the same year he left for what was then the Dutch East Indies where he was first employed at the Java Sugar Experiment Station; then, until 1921, he taught at the Medical College (N.I.A.S.). After returning to the Netherlands he lectured from 1921 to 1923 on plant physiology at the University of Amsterdam. During these years, too, his scientific work was mainly devoted to phototropy and hydrotropy. In 1924 he accepted a position as professor of botany at the 
Transvaal University College, South Africa. Initially his research there was also in plant physiology, but, perhaps partly under the influence of local conditions, partly through some shift in his interest, his work became gradually oriented toward morphology and systematics. Certain physiological problems in the Rubiaceae drew his attention to that family (Revision of the South African species of Pavetta).

In 1930 he was on leave in the Netherlands. It was on that occasion that I first met him, when he attended the awarding of a Ph. D. to one of his South African students. I had long been familiar with his name. For all students studying with Prof. Went thorough knowledge of the scientific work of "Went's school" was compulsory. Went's pupils from the days before the First World War were the scientific models that we tried to follow. Names we pronounced with some awe were, beside Bremekamp, Blaauw, Mrs. Rutten-Pekelharing, Arisz, etc. Meeting Bremekamp and being in his company at a dinner party greatly impressed me. Since that time I have known that Bremekamp was a source of information who would take great pains to answer a question as well as possible.

In 1931 he left his post in Pretoria to return to the Netherlands. Het settled in Bilthoven and was then almost daily at the Botanical Museum and Herbarium (Instituut voor Systematische Plantkunde). Since that time all of his research has been in taxonomy, always accompanied by detailed morphological studies. At first he revised the Rubiaceae and Acanthaceae for Pulle's Flora of Suriname, then he turned to monographic work in these two plant families, publishing a very large series of papers. A number of publications of a more general kind testify to his broad biological knowledge and interest. Full justice was done to his scientific merits when he was appointed a member of the Royal Dutch Academy of Sciences in 1949.

For us at Utrecht Bremekamp is still a greatly appreciated honorary research worker. He has contributed to the renown of our institute, he has been a source of information for many, and from the beginning he has rendered us invaluable services by helping us with the correcting of the English texts of our papers. His corrections were not confined to the linguistic aspect, but he often also gave advice on scientific matters in his own modest way, thereby improving the paper as a whole. In this he gave proof of his thorough knowledge of morphology.

Bremekamp's assistance in correcting English papers was often called upon, the editor's office of the periodicals of the Royal Dutch Botanical Society (Pulle, then Jonker) being for many years at Utrecht. He always gave his help disinterestedly and thereby contributed very materially to the impression which our Society has made. He has proved a worthy and active member, and we all wish him many good years to come.

J. LANJOUW 